\title{
Effect of Water Deficit on Growth, Yield and Quality of Soybean Seed Morsy, A. R. ${ }^{1}$; Amany M. Mohamed ${ }^{2}$; E. A. Abo-Marzoka ${ }^{3}$ and M. A. H. Megahed ${ }^{2}$ \\ ${ }^{1}$ Food Legume Research Department, Field Crops Research Institute, ARC, Egypt. \\ ${ }^{2}$ Seed Technology Research Department, Field Crops Research Institute, ARC, Egypt. \\ ${ }^{3}$ Crop Physiology Research Department, Field Crops Research Institute, ARC, Egypt.
}

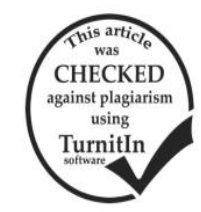

\section{ABSTRACT}

Two field experiments were carried out at Sakha Agricultural Research Station, Kafr El-Sheikh Governorate, Egypt, during 2016 and 2017 summer seasons to study the effect of water deficit on growth, yield and quality of seed of 12 soybean genotypes. Water deficit regimes were applied at 15 (recommended regime), 20 and 25 days intervals. The results of combined analysis showed significant effects of soybean genotypes, irrigation regimes and their interactions on the studied traits. Water deficit significantly decreased 100-seed weight and seed yield/feddan in both seasons. Irrigation intervals significantly influenced seed quality traits such as oil, protein, germination percentage and electrical conductivity. The 20 days interval regime resulted in high 100 -seed weight and seed yield, while the 25 days interval regime gave lower values in this respect. The percentage of oil and protein of seeds was significantly affected by water deficit, where there was a decrease in seed oil and an increase in protein content. Water deficit significantly decreased dry matter accumulation, leaf area index, crop growth rate, net assimilation rate and chlorophyll content in leaves, while relative water content and proline were significantly increased. The commercial cultivar Giza 111 produced high 100 seed weight (19.84 g) and seed yield (2.183 t/fed), followed by H14L8. On the other hand, seed germination (\%) was decreased with increasing water deficit, while seed conductivity (vigor test) was increased. Giza111 showed high seed germination percentage over all irrigation regimes with $(87.1 \%)$ as an average, whereas Toano gave low seed germination percentage (73.2\%). Generally, the genotype Giza111 is the most suitable genotype under the different irrigation regimes, whereas 416937 and DR 101 genotypes could be useful for soybean breeding program for water deficit tolerance.

Keywords: Soybean, water deficit, irrigation regimes, growth, yield, seed quality.

\section{INTRODUCTION}

Soybean (Glycine max L.) is considered one of the major oilseed crops all over the world. It is supplies represent more than $60 \%$ of the global demand of vegetable oil and protein with a worldwide production of about 334 million metric tons (USDA, 2018). In Egypt, soybean could not occupy its appropriate position due to the competition with other summer crops, low net profit per unit area and marketing problems (Morsy et al., 2017). It is therefore, Egypt imports about three million metric tons from soybean seed and about 400,000 metric tons from soybean oil only (USDA, 2018). A great interest is given to grow soybean in the new reclaimed areas outside the Nile valley. The limited water resources make the horizontal expansion in soybean area is very limited and appropriate choice is through crop intensification to maximize the productivity of water and land unit. Water restriction is the most economically important abiotic stress factors limiting soybean production worldwide and drought alone accounts for about $40 \%$ crop loss. Plant growth stages, severity and duration of drought are the main factors that affect the crop loss when subject to drought stress. Rodrigues et al., 2012 reported that soybean yield is most sensitive to water deficit during the pod filling stage of development. During flowering and early pod development stages, Tetsuji et al., 2004 stated that water deficit significantly increases the rate of flower and pod abortion, ultimately decreasing seed yield because of decreasing the seed size. Water shortage, at various stages of development in soybean plants, showed the average length of the internodes to be the most sensitive feature (Desclaux et al., 2000). Quain et al., 2014 said that stressed plants often mature earlier, shortening the grain filling period causing reduced seed weight and consequently yield reduction. It was observed that yield loss was the most severe when drought stress was occurred throughout the seed development period (R5- R7) resulting in a reduction of $45 \%$ and $88 \%$, respectively. Water deficit was significantly affected the shoot dry matter in the reproductive stages (R3R5), reduced leaf area and plant dry matter during vegetative growth (emergence to R5), reduced the leaf area indices (LAI) and the inter ceptation of photosynthetic active radiation and consequently decreased the seed yield
(Raper and Kramer, 1987). Another physiology trait that may affect drought tolerance is the decline of whole plant water used during a soil water deficit event. Production and accumulation of free amino acids, especially proline by plant tissue during water stress is an adaptive response, to adversity and is involved in the succession resistant capability of plants against the adverse effect of high concentrations of ions and may also function as a PRO compatible hydrotropic and as a hydroxyl radical (Abass and Mohamed 2011).

Proline is a metabolic marker and a highly watersoluble amino acid that can be used as in relation to stress (Burton, 1991). Proline is produced immediately after the plant subjected to the stress to protect the plasma membrane and proteins against the stress (Santoro et al., 1992).Water stress resulted in decreasing leaf water potential, relative water content and exudation rate as well as influencing leaf anatomical characteristics and photosynthetic parameters (Omae et al., 2007). Leaf chlorophyll content is an important factor determining photosynthetic capacity. Decreased or unchanged chlorophyll level during water deficit stress has been observed in other species and this was depending on water deficit duration and severity (Terzi et al., 2010). Changes in leaf chlorophyll content with water deficit and heat injury may involve a severe chlorophyll photo oxidation mediated by oxy- radicals (Abass and Mohamed 2011). The quality traits included physical and technology contents of seed protein and oil are major parameters determining the nutritional value of soybean. Chung et al., 2003 reported that soybean seed protein content, in general, is negatively correlated with the amount of seed oil. Dornbos and Mullen, 1992 observed $4.4 \%$ increase in protein content and $2.6 \%$ decrease in oil content under severe drought stress of two soybean cultivars. Furthermore, both the negative correlation between seed protein and seed oil contents as well as the effect of drought on seed protein and seed oil contents were attributed largely to the differential rainfall during the seed filling stage (Tetsuji et al., 2004).

The main objective of this study was to evaluate 12 soybean genotypes under different water deficit regimes to get benefit from the high performance 
genotypes in the soybean breeding programs for drought tolerance and grow them in the new reclaimed land.

\section{MATERIALS AND METHODS}

Consecutive two-year field experiments were conducted during 2016 and 2017 summer seasons at
Sakha Agricultural Research Station, Kafr El-Sheikh Governorate, Egypt. The code, pedigree, origin, maturity group and flower color of the genotypes are presented in Table (1).

Table 1. The pedigree, maturity group, flower color and origin of the genotypes.

\begin{tabular}{|c|c|c|c|c|c|}
\hline Code No. & Genotype & Pedigree & Maturity group & Flower color & Origin \\
\hline$\overline{\mathrm{G} 1}$ & Giza 21 & Crawford x Celest & IV & Purple & FCRI * \\
\hline $\mathrm{G} 2$ & $\begin{array}{l}\text { P1416937 } \\
416937\end{array}$ & Exotic from Japan (drought tolerant) & V & Purple & Japan \\
\hline G3 & Giza 83 & $\begin{array}{c}\text { Selected from MBB-133-9Union x L 76- } \\
038 \text { (Williams x PI 171451) }\end{array}$ & III & White & FCRI * \\
\hline G4 & Giza 111 & Crawford $\mathrm{x}$ Celest & IV & Purple & FCRI * \\
\hline G5 & $\mathrm{H}_{1} \mathrm{~L}_{30}$ & Crawford x L 62-1686 & III & Purple & FCRI * \\
\hline G6 & $\mathrm{H}_{1} \mathrm{~L}_{32}$ & Giza 21 x 186 k-73 & IV & White & FCRI * \\
\hline G7 & Toano & Ware x Essex & V & Purple & AES, USA ** \\
\hline G8 & DR101 & Selected from Elgin (drought tolerant) & V & Purple & FCRI * \\
\hline G9 & $\mathrm{H}_{14} \mathrm{~L}_{8}$ & Holladay $\mathrm{X} \mathrm{H}_{2} \mathrm{~L}_{12}$ & IV & Purple & FCRI * \\
\hline G10 & L 162 & Toano x (L 86- K- 73 x Toano) & IV & Purple & FCRI * \\
\hline G11 & Giza 35 & Crawford x Celest & III & Purple & FCRI * \\
\hline G12 & Holladay & N 77-179 x Johnston & V & Purple & AES, USA ** \\
\hline
\end{tabular}

* FCRI = Field Crops Research Institute, Giza, Egypt. $\quad * *$ AES, USA = Agricultural Experiment Station, USA.

Three types of irrigation regimes were applied as follows:

- (T1) Irrigation at 15 days interval (recommended).

- (T2) Irrigation at 20 days interval.

- (T3) Irrigation at 25days interval.

Each irrigation regime was conducted in a separate experiment to perform accurate application for the different irrigation regimes and the genotypes were distributed in a Randomized Complete Block Design with three replications. A combined analysis was done for all experiments. Each plot consisted of six ridges. Each ridge was $4 \mathrm{~m}$ long and the distance between the ridges was $0.70 \mathrm{~m}$. Seeds of all genotypes were inoculated with the specific rhizobia prior to planting and other agricultural practices were applied as recommended. Plant samples were taken from the outer two ridges of each plot at 70 days from planting (DFP). Dry matter accumulation ( $\mathrm{g} / \mathrm{plant}$ ), leaf area index, relative water content, crop growth rate and net assimilation rate, Chlorophyll and proline content in leaves were studied. Leaf relative water content (RWC) was determined according to Ritchie and Nguyen (1990). Crop growth rate (CGR) and net assimilation rate (NAR) were determined according to Radford (1967). Total chlorophyll was determined using the spectro-photometric method according to Moran, (1982). Leaf proline content was determined according to Bates et al., (1973). At harvest, seed yield was determined from the central four ridges of each plot in kilograms and transformed to kilograms per feddan $\left(1 \mathrm{fed}=4200 \mathrm{~m}^{2}\right)$. In addition, a seed sample of $50 \mathrm{~g}$ from each replicate was randomly taken to determine 100-seed weight, standard germination, and oil and protein contents. Standard germination test and the electrical conductivity (EC) were carried out according to the international rules of testing ISTA, (1999). Seed protein and oil contents were determined according to procedures outlined in AOAC (1990).

Statistical analysis:

Data was statistically analyzed according to Gomez and Gomez (1984) for each season separately and combined analysis over the two seasons. Means of treatments were compared by used least significant difference (LSD) at 5\% level of significant.

\section{RESULTS AND DISCUSSION}

Data recoded in Figs (1-7) show that water deficit had a significant effect on the studied traits. Delaying irrigation from 15 days interval to irrigation at 25 days interval significantly decreased dry matter accumulation (g/plant), leaf area index, crop growth rate $\left(\mathrm{g} / \mathrm{m}^{2} /\right.$ week), net assimilation rate $(\mathrm{g} / \mathrm{g} /$ week $)$ and Chlorophyll $\left(\mathrm{mg} / \mathrm{dm}^{2}\right)$ content of leaves from $[109.5(\mathrm{~g}), 7.0,9.3(\mathrm{~g}), 4.6(\mathrm{~g})$, and $4.9(\mathrm{mg})]$, respectively to $[80.9(\mathrm{~g}), 5.8,6.4(\mathrm{~g}), 3.9(\mathrm{~g})$ and $4.6(\mathrm{mg})]$, respectively. In the meantime, relative water content and proline were significantly increased from $\left(43.2 \%\right.$ and $\left.37.5 \mu \mathrm{m} \mathrm{g}^{-1}\right)$ to $\left(53.5 \%\right.$ and $\left.45.4 \mu \mathrm{m} \mathrm{g}^{-1}\right)$, respectively.

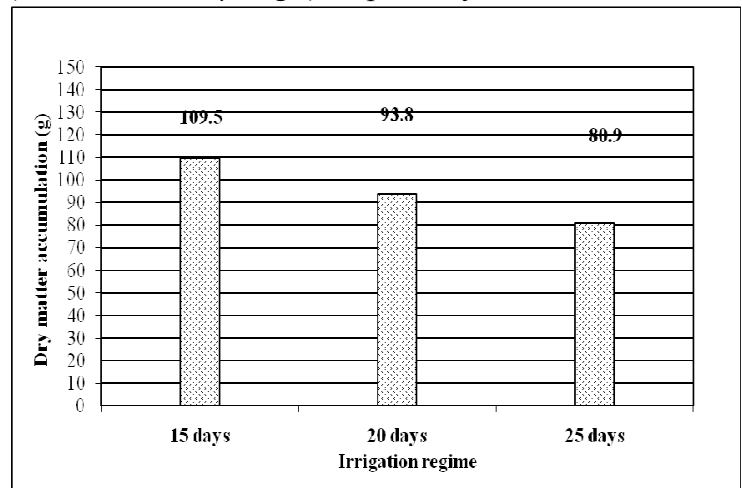

Fig. 1. Effect of irrigation regimes on dry matter (g/plant)

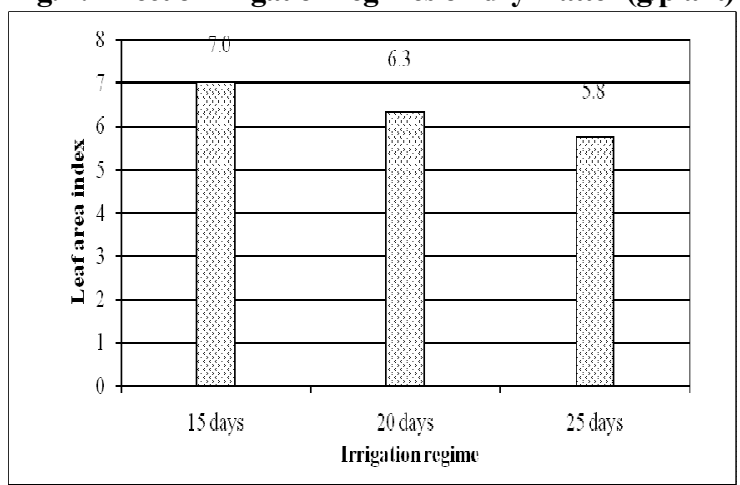

Fig. 2. Effect of irrigation regimes on leaf area index 


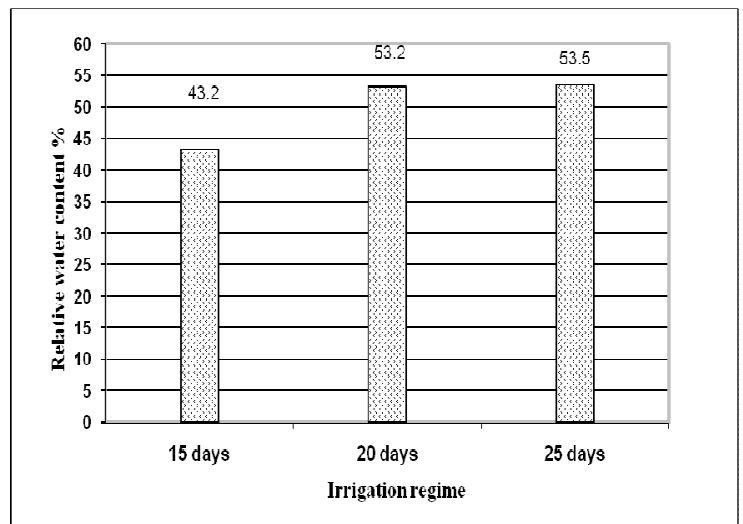

Fig. 3. Effect of irrigation regimes on RWC\%.

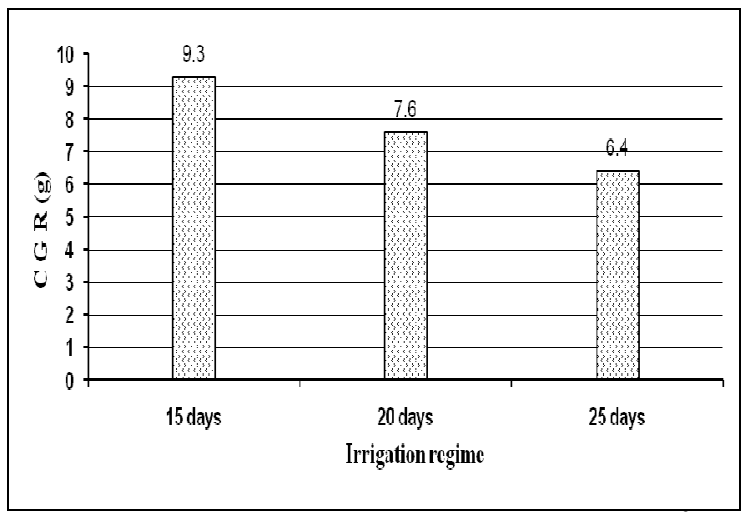

Fig. 4. Effect of irrigation regimes on CGR $\mathrm{g} / \mathrm{m}^{2}$

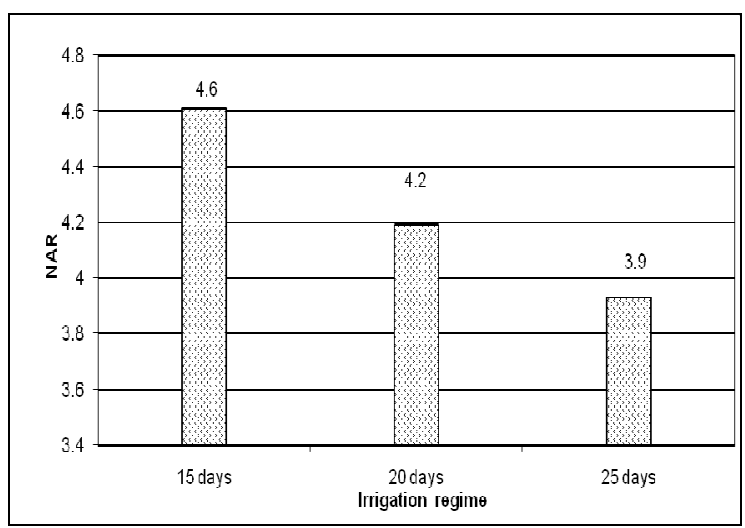

Fig. 5. Effect of irrigation regimes on NAR (g/g/week).

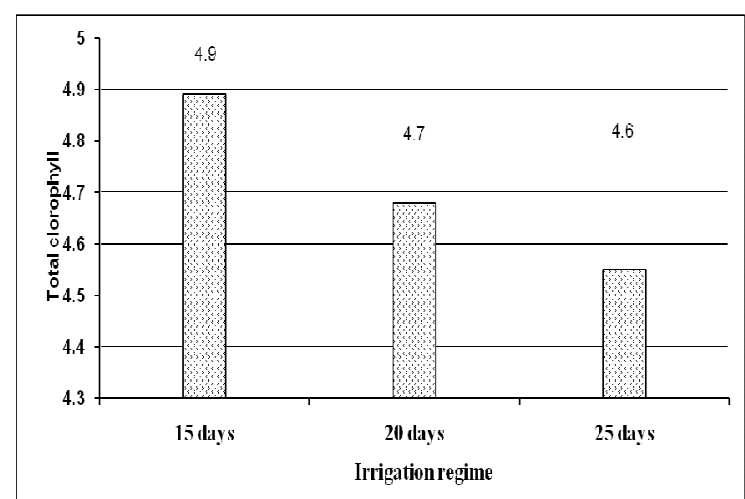

Fig. 6. Effect of irrigation regimes on total chlorophyll $\left(\mathrm{mg} / \mathbf{d m}^{2} / \mathrm{FW}\right)$.

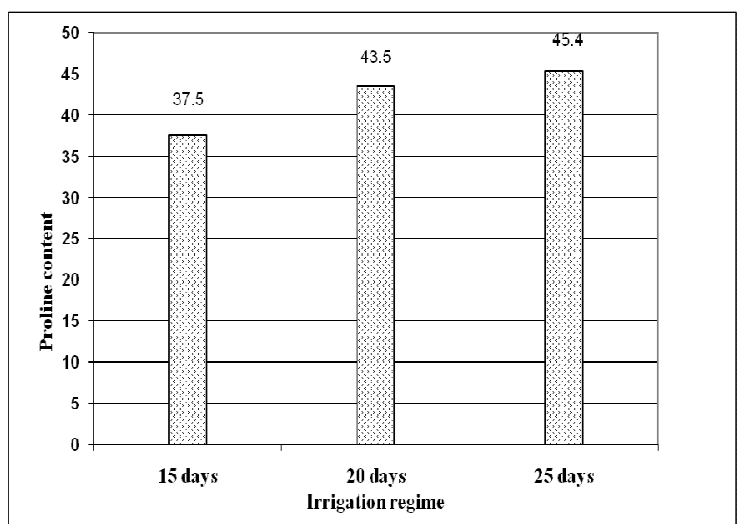

Fig. 7. Effect of irrigation regimes on proline $\left(\mu \mathrm{m} \mathrm{g}^{-1}\right)$.

These results are in agreed with Abass and Mohamed (2011) who reported that the water deficit condition caused significant increase in the proline and soluble sugars content in shoot of common bean plants. Also, Proline can act as a signaling molecule to modulate mitochondrial functions, influence cell proliferation or cell death and trigger a specific gene expression, which can be essential for plant recovery from water stress.

The results in (Table 2) showed differences among soybean genotypes in most growth characters. It is obvious that PI 416937 and DR 101 genotypes had the higher values of dry matter accumulation (108.2 and $104.2 \mathrm{~g} /$ plant), leaf area index (6.9 and 6.9), relative water content (54.6 and $54.5 \%$ ), crop growth rate $\left(9.5\right.$ and $9.4 \mathrm{~g} / \mathrm{m}^{2} /$ week), net assimilation rate (4.8 and $4.8 \mathrm{~g} / \mathrm{g} / \mathrm{week})$, total chlorophyll (5.2 and $5.0 \mathrm{mg} / \mathrm{dm}^{2}$ ) and proline content of leaves ( 45.7 and $45.1 \mu \mathrm{mol} \mathrm{g}^{-1}$ of FW), respectively. Giza 21 had the lower value of dry matter accumulation ( $84.5 \mathrm{~g} / \mathrm{plant})$, leaf area index (5.7), relative water content (41.9\%), Chlorophyll (4.2) and proline content of leaves $(37.3 \mathrm{mg})$, respectively. On the other hand, Toano recorded the lower value of net assimilation rate $(3.8 \mathrm{~g})$ over different irrigation regimes. Similar results were obtained by El-Garhy et al (2008). It is important to note that DR101 and L117 genotypes were significantly high in dry matter accumulation (g/plant), leaf area index, relative water content, crop growth rate, net assimilation rate, Chlorophyll and proline content of leaves.

Water deficit caused significant decrease in chlorophyll and total photosynthetic pigments in leaves of soybean plant as compared with control plants (Table 2). Similar results were reported by Terzi et al., (2010) in some soybean genotypes and these pigments were sensitive to increasing environmental stress. The decrease in these pigments may have resulted from a decrease in leaf water status of soybean plants. Genotypes DR101 and PI416937 were pronounced and continued until day 15 of the dry cycle (Table 6), whereas DR101 and PI 416937 maintained greater leaf Chlorophyll content during the entire period of drought stress cycles. At 15 days interval, the higher Chlorophyll content (5.2 and $5.0 \mathrm{mg} / \mathrm{dm}^{2}$ ) was recorded for PI416937, followed by Giza83 $\left(4.44 \mathrm{mg} / \mathrm{dm}^{2}\right)$ and the lower one $\left(4.2 \mathrm{mg} / \mathrm{dm}^{2}\right)$ was recorded for Giza21. The leaf proline content of the drought-tolerant genotypes (DR101 and PI416937) was unchanged as water restriction progressed until 15 days, while the proline content of droughtsusceptible genotype (Giza 21) markedly increased after 
Morsy, A. R. et al.

withholding of water. The proline level of the tolerant genotypes declined sharply and reached almost the well- watered level by one day after rewetting, the proline content of soybean plants significantly increased under water deficit.

Table 2. Mean performance of soybean genotypes of studied characters at different irrigation regimes.

\begin{tabular}{|c|c|c|c|c|c|c|c|}
\hline $\begin{array}{l}\text { Characters } \\
\text { Genotypes }\end{array}$ & $\begin{array}{l}\text { Dry matter } \\
\text { (g/plant) } \\
70 \text { DFP }\end{array}$ & $\begin{array}{l}\text { leaf area } \\
\text { index } \\
70 \mathrm{DFP}\end{array}$ & $\begin{array}{c}\text { Relative water } \\
\text { Content (RWC) }(\%) \\
70 \text { DFP }\end{array}$ & $\begin{array}{l}\text { CG R } \\
\text { (g/ m } \\
\text { /week) }\end{array}$ & $\begin{array}{l}\text { NAR } \\
\text { (g/g/ } \\
\text { week) }\end{array}$ & $\begin{array}{c}\text { Total } \\
\text { Chlorophyll } \\
\left(\mathbf{m g} / \mathbf{d m}^{2}\right)\end{array}$ & $\underset{\left(\mu \mathrm{m} \mathbf{g}^{-1} \text { of }\right.}{\text { Proline }}$ \\
\hline 1-Giza 21 & 84.5 & 5.7 & 41.9 & 7.1 & 4.4 & 4.2 & 37.3 \\
\hline 2-PI 416937 & 104.2 & 6.9 & 54.6 & 9.4 & 4.8 & 5.0 & 45.1 \\
\hline 3-Giza 83 & 86.9 & 6.1 & 48.0 & 5.4 & 3.1 & 4.4 & 40.1 \\
\hline 4-Giza 111 & 89.2 & 6.2 & 48.5 & 8.2 & 4.3 & 4.5 & 40.6 \\
\hline $5-\mathrm{H} 30$ & 89.4 & 6.2 & 48.9 & 8.1 & 4.7 & 4.6 & 41.1 \\
\hline 6-H32 & 94.0 & 6.3 & 49.3 & 7.2 & 4.0 & 4.6 & 41.9 \\
\hline 7-Toano & 90.6 & 6.3 & 49.8 & 6.8 & 3.8 & 4.7 & 42.7 \\
\hline 8-DR 101 & 108.2 & 6.9 & 54.5 & 9.5 & 4.8 & 5.2 & 45.7 \\
\hline 9-H 14 L 8 & 98.7 & 6.4 & 50.2 & 7.6 & 4.2 & 4.7 & 41.8 \\
\hline 10-L 162 & 96.4 & 6.4 & 50.8 & 8.0 & 4.4 & 4.7 & 42.3 \\
\hline 11-Giza 35 & 97.3 & 6.5 & 51.3 & 7.8 & 4.2 & 4.9 & 43.1 \\
\hline 12-Holladay & 97.6 & 6.6 & 51.7 & 8.1 & 4.3 & 4.9 & 43.7 \\
\hline F-test & $* *$ & $*$ & $*$ & 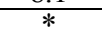 & $\cdots$ & 4 & 0 \\
\hline L.S.D at 0.05 & 0.98 & 1.48 & 0.28 & 4.81 & 0.32 & 0.06 & 0.74 \\
\hline
\end{tabular}

The interaction between irrigation regimes and genotypes revealed highly significant differences for dry matter accumulation, crop growth rate, net assimilation rate, Chlorophyll and proline content (Tables 3 and 4). At 15 days interval, DR101 genotype gave the higher values of dry matter accumulation (120.6 g), CGR (11.9 g/ m²), NAR $(5.6 \mathrm{~g})$ and total Chlorophyll $\left(5.4 \mathrm{mg} / \mathrm{dm}^{2}\right)$, respectively, while PI416937 genotype recorded the higher value of leaf area index (7.6). On the other hand, the lower dry matter accumulation and leaf area index (68.6 $\mathrm{g}$ and 5.6) were recorded by $\mathrm{H} 30$ genotype, while Giza 83 had the lower values of CGR and NAR (4.7 g and $3.0 \mathrm{~g}$ ). At 25 days interval, Giza 21 had lower Chlorophyll content $\left(4.2 \mathrm{mg} / \mathrm{dm}^{2}\right)$, while DR 101 and PI 416937 had the higher relative water and proline contents of leaves.

Table 3. Interaction effect of irrigation regime and genotypes on dry matter accumulation, leaf area index, relative water content and crop growth rate.

\begin{tabular}{|c|c|c|c|c|c|c|c|c|c|c|c|c|}
\hline \multirow{2}{*}{$\begin{array}{l}\text { Characters and treatment } \\
\text { Genotvpes }\end{array}$} & \multicolumn{3}{|c|}{ Dry matter (g/plant) } & \multicolumn{3}{|c|}{ leaf area index } & \multicolumn{3}{|c|}{ Relative water Content (RWC) (\%) } & \multicolumn{3}{|c|}{ C G R (g/ m²/week) } \\
\hline & T1 & T2 & T3 & T1 & $\mathbf{T 2}$ & T3 & T1 & $\mathbf{T 2}$ & T3 & T1 & T2 & T3 \\
\hline Giza 21 & 101.8 & 80.2 & 71.5 & 6.4 & 5.4 & 5.2 & 37.3 & 42.2 & 46.3 & 8.7 & 6.8 & 5.9 \\
\hline P1416937 & 118.9 & 102.2 & 91.5 & 7.6 & 6.9 & 6.2 & 47.1 & 58.3 & 58.4 & 10.7 & 9.1 & 8.3 \\
\hline Giza83 & 110.4 & 78.5 & 71.7 & 6.7 & 6.1 & 5.5 & 41.4 & 51.3 & 51.3 & 6.3 & 5.2 & 4.7 \\
\hline Giza111 & 106.9 & 87.9 & 72.9 & 6.8 & 6.2 & 5.6 & 41.9 & 51.8 & 51.8 & 10.1 & 7.8 & 6.7 \\
\hline $\mathrm{H} 30$ & 107.9 & 91.8 & 68.6 & 6.8 & 6.2 & 5.6 & 42.2 & 52.3 & 52.3 & 10.2 & 8.1 & 6.0 \\
\hline $\mathrm{H} 32$ & 108.8 & 94.7 & 78.6 & 6.9 & 6.3 & 5.7 & 42.6 & 52.7 & 52.7 & 8.6 & 7.2 & 5.8 \\
\hline Toano & 102.8 & 91.6 & 77.4 & 7.0 & 6.3 & 5.7 & 42.9 & 53.2 & 53.2 & 8.0 & 7.0 & 5.4 \\
\hline DR101 & 120.6 & 109.8 & 77.38 & 7.6 & 6.9 & 6.2 & 47.0 & 58.3 & 58.3 & 11.9 & 9.3 & 7.5 \\
\hline H14L8 & 107.9 & 95.6 & 92.5 & 7.0 & 6.4 & 5.8 & 43.3 & 53.6 & 53.6 & 9.5 & 7.1 & 6.1 \\
\hline L162 & 108.0 & 97.5 & 83.8 & 7.1 & 6.4 & 5.8 & 44.8 & 54.3 & 54.3 & 9.3 & 7.8 & 6.9 \\
\hline Giza35 & 106.9 & 98.9 & 86.1 & 7.1 & 6.5 & 5.9 & 44.2 & 54.8 & 54.8 & 8.7 & 7.8 & 7.0 \\
\hline Holladay & 113.6 & 97.5 & 81.8 & 7.2 & 6.5 & 5.9 & 44.6 & 55.2 & 55.2 & 9.6 & 7.8 & 6.7 \\
\hline F-test & & $* *$ & & & $* *$ & & & $* *$ & & & NS & \\
\hline L.S.D 0.05 & & 2.01 & & & 4.24 & & & 1.03 & & & - & \\
\hline
\end{tabular}

** and NS indicated. to significant and not significant at $\mathbf{P}<0.01$, respectively.

Table 4. Interaction effect of irrigation regime and genotypes on net assimilation, chlorophyll and proline content.

\begin{tabular}{|c|c|c|c|c|c|c|c|c|c|}
\hline \multirow{2}{*}{$\begin{array}{l}\text { Characters and } \\
\text { Treatments } \\
\text { Genotypes }\end{array}$} & \multicolumn{3}{|c|}{$\begin{array}{c}\text { NA R } \\
(\text { g/g/week) }\end{array}$} & \multicolumn{3}{|c|}{$\begin{array}{c}\text { Total Chlorophyll } \\
\left(\mathrm{mg} / \mathrm{dm}^{2} / \mathrm{FW}\right)\end{array}$} & \multicolumn{3}{|c|}{$\begin{array}{c}\text { Proline } \\
\left(\mu \mathrm{m} \mathrm{g}^{-1} \text { of } \mathrm{FW}\right)\end{array}$} \\
\hline & T1 & T2 & T3 & T1 & T2 & T3 & T1 & T2 & T3 \\
\hline Giza 21 & 4.9 & 4.4 & 4.0 & 4.4 & 4.1 & 4.1 & 33.1 & 38.2 & 40.6 \\
\hline P1416937 & 5.0 & 4.7 & 4.6 & 5.1 & 5.0 & 4.9 & 40.2 & 46.8 & 48.3 \\
\hline Giza83 & 3.4 & 3.0 & 3.0 & 4.6 & 4.4 & 4.3 & 35.5 & 40.9 & 43.9 \\
\hline Giza111 & 4.1 & 4.4 & 4.2 & 4.7 & 4.5 & 4.3 & 36.2 & 41.6 & 44.1 \\
\hline $\mathrm{H} 30$ & 4.9 & 4.6 & 4.5 & 4.8 & 4.6 & 4.4 & 37.0 & 42.1 & 44.3 \\
\hline H32 & 4.4 & 4.0 & 3.6 & 4.8 & 4.6 & 4.5 & 37.4 & 42.9 & 45.4 \\
\hline Toano & 4.1 & 3.9 & 3.3 & 4.9 & 4.7 & 4.5 & 38.5 & 43.8 & 45.9 \\
\hline DR101 & 5.6 & 4.7 & 4.2 & 5.4 & 5.1 & 5.0 & 40.4 & 47.6 & 49.0 \\
\hline H14L8 & 4.8 & 3.9 & 3.7 & 4.9 & 4.7 & 4.6 & 36.8 & 44.0 & 44.7 \\
\hline L162 & 4.7 & 4.3 & 4.1 & 4.9 & 4.7 & 4.6 & 37.3 & 44.2 & 45.4 \\
\hline Giza35 & 4.4 & 4.2 & 4.2 & 5.1 & 4.8 & 4.7 & 38.8 & 44.4 & 46.2 \\
\hline Holladay & 4.8 & 4.2 & 4.0 & 5.1 & 4.9 & 4.8 & 39.3 & 45.0 & 46.7 \\
\hline F-test & \multicolumn{3}{|c|}{$\mathrm{NS}$} & \multicolumn{3}{|c|}{$* *$} & \multicolumn{3}{|c|}{$* *$} \\
\hline L.S.D 0.05 & \multicolumn{3}{|c|}{-} & \multicolumn{3}{|c|}{1.98} & \multicolumn{3}{|c|}{3.03} \\
\hline
\end{tabular}

** and NS indicated. to significant and not significant at $\mathrm{P}<0.01$, respectively. 


\section{J. Plant Production, Mansoura Univ., Vol. 9 (8), August, 2018}

Data in Figs. (8 and 9) clearly showed that water deficit had a significant effect on 100-seed weight and seed yield. Delaying irrigation from 15 days interval to 25 days interval significantly decreased the 100-seed weight (18.69 g) and seed yield (2.141t/fed) comparing with irrigation at 25 days interval (16.58 $\mathrm{g}$ and $1.619 \mathrm{t} /$ fed.). The higher values of seed yield traits were obtained when irrigation duration was 20 days interval.

In addition, seed germination (\%) was significantly decreased from $89.9 \%$ when irrigation was 15 days interval to $63.5 \%$ at 25 days interval. On the other hand, delaying irrigation to 25 days interval was significantly increased the seed conductivity from 23.0 to $27.7 \mu$-mhos (Figs. 10 and 11). In this aspect, Prisco et al., (1992) reported that increasing the water deficit, decreasing the germination (\%). Also, Fougereux et al., (1997) observed that water deficit during the seed filling period reduced seed quality. Similar results have been reported by El- Borai et al., (1993).

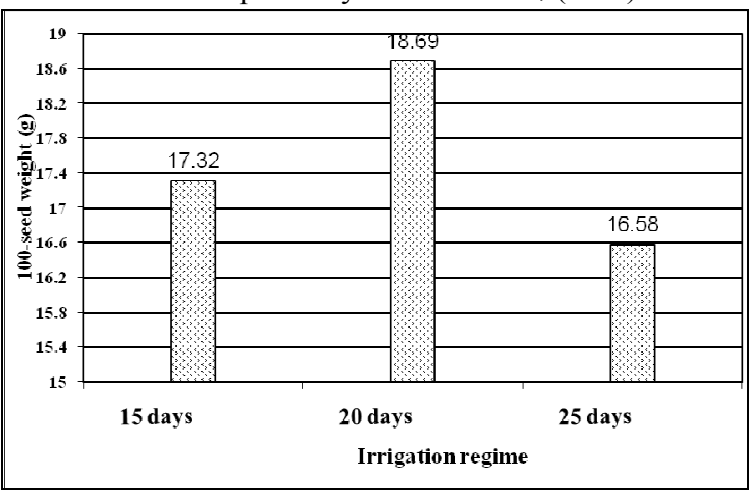

Fig. 8. Effect of irrigation regimes on100- seed weight (g).

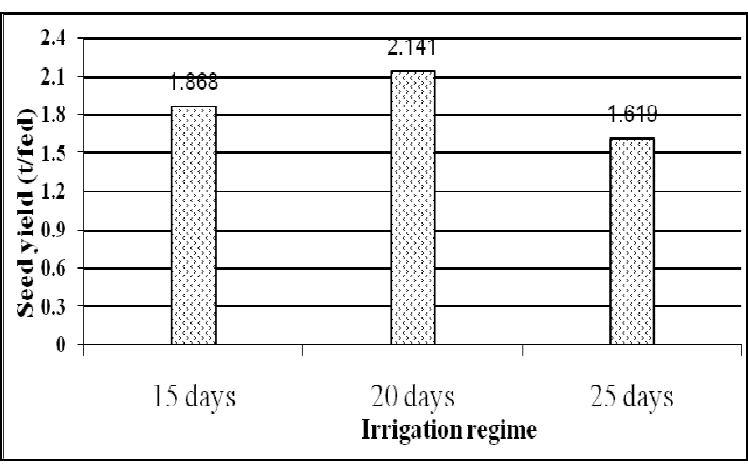

Fig. 9. Effect of irrigation regimes on seed yield ( $t /$ fed).

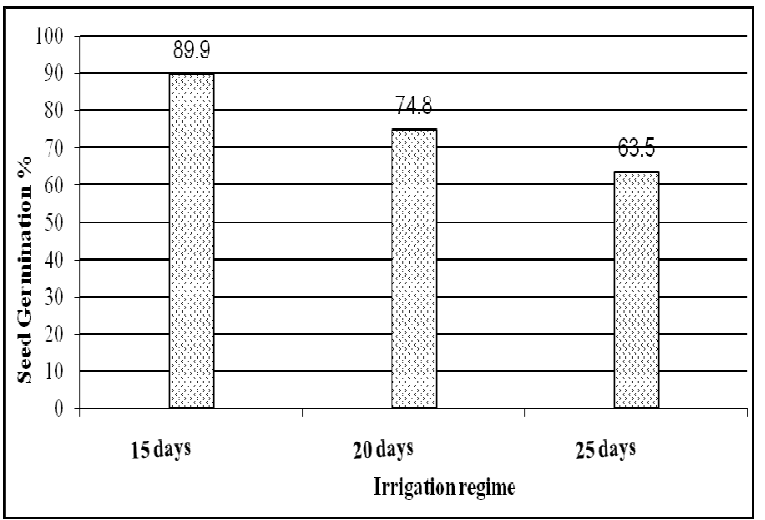

Fig. 10. Effect of irrigation regimes on seed germination $\%$.

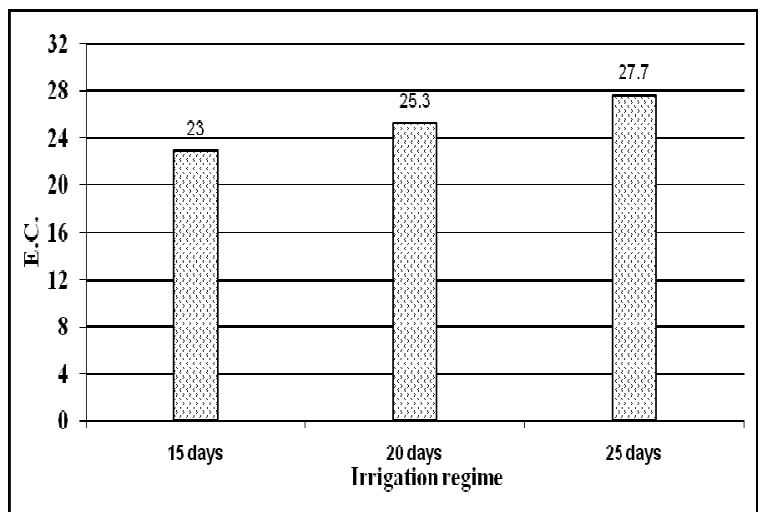

Fig. 11. Effect of irrigation regimes on EC.

Delaying irrigation from 15 days interval to 25 days interval significantly decreased seed oil content from 24.9 $\%$ to $20.4 \%$, while seed protein content was significantly increased from 37.3 to $38.8 \%$ (Figs. 12 and 13). In general, it was negatively correlated with the amount of seed oil. Similar results have been reported by Latifi (1989) who reported that increased protein and decreased oil of soybean were associated with irrigation at early pod set and seed filling. In general, these results are in agreement with those obtained by Abd El-Mohsen et al., (2013) and ElSabagh et al., (2015). However, El -Borai et al., (1993) obtained the opposite results, where the irrigation had no effect on the seed oil content of soybean. Water deficit conditions increased protein and decreased oil contents in rap due to changes in the embryo, endosperm and testa (Henry and McDonald, 1978).

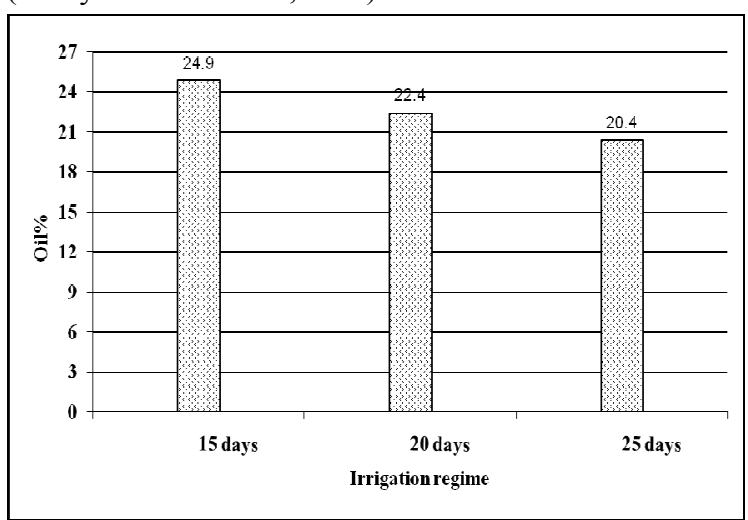

Fig. 12. Effect of irrigation regimes on seed oil \%.

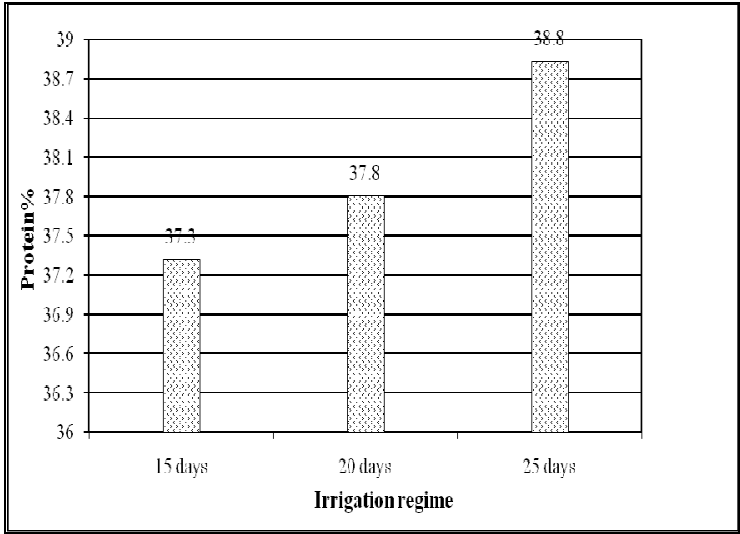

Fig. 13. Effect of irrigation regimes on seed protein $\%$. 
Data in Table (5) showed that Giza 111 cultivar had the high 100 -seed weight and seed yield fed $^{-1}$ (19.84g and $2.183 \mathrm{t} / \mathrm{fed})$, respectively over all irrigation regimes followed by H14 L8 and Giza 21(18.99, 18.71g, 2.069 and 2.003 ton $\mathrm{fed}^{-1}$ ), respectively. Giza 35 had the lower100seed weight value (15.59g), and PI 416937 genotype had the low seed yield fed ${ }^{-1}(1.647 \mathrm{t} / \mathrm{fed})$.

Table 5. Mean performance of soybean genotypes as to yield and quality of seeds produced under different irrigation regimes.

\begin{tabular}{|c|c|c|c|c|c|c|}
\hline Characters & 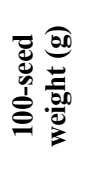 & 宽 & 总 & 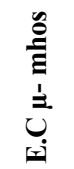 & $\frac{\partial^{\circ}}{\bar{\sigma}}$ & 造起 \\
\hline \multicolumn{7}{|c|}{ Genotypes } \\
\hline Giza 21 & 18.71 & 2.003 & 75.2 & 23.9 & 24.2 & 37.8 \\
\hline PI 416937 & 15.77 & 1.647 & 82.8 & 9.5 & 22.1 & 41.6 \\
\hline Giza83 & 17.50 & 1.903 & 74.2 & 33.3 & 22.1 & 43.2 \\
\hline Giza111 & 19.84 & 2.183 & 87.1 & 18.5 & 22.6 & 41.4 \\
\hline H30 & 16.76 & 1.851 & 86.7 & 19.3 & 20.7 & 37.7 \\
\hline H32 & 17.26 & 1.894 & 76.6 & 23.0 & 21.5 & 38.0 \\
\hline Toano & 16.74 & 1.750 & 73.2 & 34.5 & 22.0 & 37.5 \\
\hline DR101 & 16.26 & 1.692 & 77.1 & 22.2 & 22.3 & 34.5 \\
\hline H14L8 & 19.00 & 2.069 & 75.4 & 23.9 & 23.9 & 38.4 \\
\hline L162 & 18.11 & 1.931 & 74.2 & 31.6 & 22.6 & 37.9 \\
\hline Giza35 & 15.59 & 1.936 & 75.2 & 26.8 & 21.8 & 31.8 \\
\hline Holladay & 15.79 & 1.650 & 75.1 & 27.6 & 23.0 & 36.0 \\
\hline F-test & $* *$ & $* *$ & $* *$ & $* *$ & $* *$ & ** \\
\hline L.S.D 0.05 & 0.64 & 0.28 & 4.34 & 0.73 & 0.54 & 0.46 \\
\hline
\end{tabular}

Reduction in soybean seed yield as a result of water deficit has also been reported by El-Borai et al., (1993), Desclaux et al., (2000) and El-Sabagh et al., (2015). It is to be noted that maximum seed yield would be obtained when crop was grown under irrigation of 20 days interval. This may be attributed to the fact that increasing soil moisture during vegetative and reproductive growth of soybean plants increased yield and its components (Gardner et al., 1985). Shortening of seed filling period due to water deficit and decreased of transferring assimilates into seeds due to water deficit are considered two major reasons for reduction of soybean yield productivity (Frederick et al., 2001). In addition, the difference in seed yield may be due to genetic makeup of different genotypes. Soybean genotypes significantly differed in seed germination (\%), where Giza 111 recorded the high value (87.1\%) followed by $\mathrm{H} 30$ (86.7\%) and PI 416937 (82.8\%), while Toano and L162 genotypes gave the low values (73.2 and $74.2 \%$ ), respectively over all irrigation regimes. On the other hand, data in Table (5) showed that PI 416937 genotype recorded the low value of E.C., while Toano recorded the high value one over all irrigation regimes. Regarding to the oil and protein contents of seeds under different levels of water deficit, the results indicated that Giza 21 had the high oil content $(24.2 \%)$, while H30 genotype had the low value (20.7\%). Giza 83 and PI 416937 had the high protein content (43.2 and 41.6\%, respectively), while Giza 35 had the low one (31.8\%).

Data in Table (6) showed that the interaction between water deficit and genotypes revealed significant differences for 100-seed weight and seed yield fed ${ }^{-1}$. Giza 111 cultivar recorded the high 100-seed weight and seed yield $\mathrm{fed}^{-1}$ (21.64 $\mathrm{g}$ and $2.642 \mathrm{t} \mathrm{fed}^{-1}$, respectively) under irrigation 20 days interval (T2). Toano genotype gave the low seed yield (1.308 ton $\left.\mathrm{fed}^{-1}\right)$ at 25 days interval (T3), while the low one (13.98 g) was Holloday genotype.

Table 6. Interaction effect of irrigation regimes and soybean genotypes on 100-seed weight (g) and seed yield ( $t /$ fed.).

\begin{tabular}{lcccccc}
\hline Characters & \multicolumn{3}{c}{ 100-seed weight(g) } & \multicolumn{3}{c}{ Seed yield(t/fed) } \\
\cline { 2 - 7 } $\begin{array}{l}\text { and treatment } \\
\text { Genotypes }\end{array}$ & T1 & T2 & T3 & T1 & T2 & T3 \\
\hline Giza 21 & 19.36 & 20.67 & 15.59 & 1.958 & 2.400 & 1.650 \\
PI 416937 & 15.70 & 16.39 & 14.80 & 1.575 & 2.033 & 1.333 \\
Giza83 & 17.35 & 17.61 & 17.03 & 1.783 & 2.195 & 1.730 \\
Giza111 & 19.12 & 21.63 & 18.27 & 2.200 & 2.642 & 1.708 \\
H30 & 16.50 & 19.17 & 14.11 & 1.730 & 2.183 & 1.637 \\
H32 & 16.65 & 18.86 & 15.76 & 1.960 & 2.092 & 1.625 \\
Toano & 15.94 & 17.97 & 15.90 & 1.870 & 2.067 & 1.308 \\
DR101 & 15.96 & 16.56 & 15.74 & 1.820 & 1.665 & 1.599 \\
H14L8 & 18.10 & 20.84 & 17.52 & 2.100 & 2.150 & 1.950 \\
L162 & 18.43 & 19.13 & 16.26 & 1.850 & 2.308 & 1.625 \\
Giza35 & 18.51 & 19.28 & 17.46 & 1.980 & 2.225 & 1.600 \\
Holladay & 14.28 & 18.62 & 13.97 & 1.540 & 1.733 & 1.667 \\
\hline F-test & \multicolumn{3}{c}{$* *$} & & & $* *$ \\
L.S.D 0.05 & \multicolumn{3}{c}{0.32} & & & 0.14 \\
\hline
\end{tabular}

Data in Table (7) showed that seed viability, as expressed of seed germination (\%) and electrical conductivity values, were significantly affected by the interaction between water deficit and soybean genotypes. The high germination percentage $(97.5 \%)$ was recorded by Giza 111 at 15 days interval (recommended regime), while the low value $(52.7 \%)$ was recorded by $\mathrm{H} 32$ at 25 days interval.

The high electrical conductivity value (36.7 $\mu$ mhos) was recorded by Toano genotype at 25 days interval, while the low value (17.2 $\mu$-mhos) was recorded by Giza 111 at 15 days interval. Data in Table (7) showed that oil and protein content of seeds were significantly affected by the interaction between irrigation regimes and genotypes. Giza 21 recorded high value of oil content $(25.3 \%)$ at 15 days interval, while H30 genotype gave the low value (18.0\%). Also, Giza 83 and P1416937 recorded higher values of protein content (44\%) and (43.9\%), respectively at 25 days interval, while Giza 35 genotype gave the low value (32.1\%) at 20 days interval.

The correlation coefficient among soybean characters in combined data was given in Table (8). The results showed that the seed yield was positively and significantly correlated with 100 -seed weight $\left(\mathrm{r}=0.808^{* *}\right)$ and germination percentage $\left(\mathrm{r}=0.403^{* *}\right)$, while the analysis of simple correlation coefficients showed negative and significant correlations between seed yield and each of oil content $(\mathrm{r}=0.382 *)$ and protein content $(\mathrm{r}=0.355 *)$. These results are in agreement with Abd El- Mohsen et al., (2013).

Seed germination was negatively and significantly correlated with EC, RWC and proline, while it showed highly significant and positive correlation with each of oil content $\%$, dry matter accumulation, leaf area index, crop growth rate and net assimilation. Furthermore, EC showed significant and negative correlated with both dry matter accumulation, crop growth rate (CGR) and net assimilation (NAR). On the other hand, oil content showed significant and negative correlated with protein content $\left(\mathrm{r}=-0.450^{*}\right)$, RWC $\left(\mathrm{r}=-0.610^{* *}\right)$ and proline $\left(\mathrm{r}=-0.683^{* *}\right)$, while it showed significant and positive correlation with each of dry matter accumulation, leaf area index, crop growth rate (CGR) and net assimilation (NAR). A negative correlation was observed between protein content $(\%)$ and each of dry matter accumulation $(\mathrm{r}=-0.367 *)$, leaf area index $\left(\mathrm{r}=-0.333^{*}\right)$, crop 
growth rate $(\mathrm{CGR} r=-0.360 *)$, net assimilation (NAR r=$0.397 *)$ and total chlorophyll $(\mathrm{r}=-0.371 *)$. Positive and highly significant correlation was observed between leaf area index $\left(\mathrm{r}=0.945^{* *}\right)$, crop growth rate $\left(\mathrm{r}=0.856^{* *}\right)$, net assimilation $\left(\mathrm{r}=0.621^{* *}\right)$ and total chlorophyll $\left(\mathrm{r}=0.481^{* *}\right)$, while it showed significant negative correlation with both RWC and proline.

Leaf area index showed negative correlation with proline accumulation $\left(\mathrm{r}=-0.387^{*}\right)$, while it showed significant and positive correlation with each of CGR,
NAR and total chlorophyll. Positive correlation was observed between RWC and proline. Furthermore, crop growth rate (CGR) showed highly significant and positive correlation with NAR $\left(\mathrm{r}=0.891^{* *}\right)$ and total chlorophyll $\left(\mathrm{r}=0.491^{* *}\right)$, while it showed negative significant correlation with proline accumulation $(\mathrm{r}=-0.372 *)$. In addition, positive correlation between net assimilation and total chlorophyll was observed. These results are in agreement with Dornbos and Mullen (1992).

\begin{tabular}{|c|c|c|c|c|c|c|c|c|c|c|c|c|}
\hline \multirow{2}{*}{$\begin{array}{l}\text { Characters and Treatments } \\
\text { Genotypes }\end{array}$} & \multicolumn{3}{|c|}{ Germination\% } & \multicolumn{3}{|c|}{ E.C $\mu$-mhos } & \multicolumn{3}{|c|}{ Oil\% } & \multicolumn{3}{|c|}{ Protein\% } \\
\hline & T1 & $\mathbf{T 2}$ & T3 & T1 & T2 & T3 & T1 & T2 & T3 & T1 & $\mathbf{T 2}$ & T3 \\
\hline Giza 21 & 93.0 & 75.3 & 57.3 & 22.4 & 23.3 & 26.1 & 25.3 & 24.2 & 23.0 & 37.1 & 37.9 & 38.6 \\
\hline PI 416937 & 93.0 & 75.0 & 70.3 & 18.7 & 19.0 & 20.8 & 23.0 & 22.0 & 21.4 & 38.5 & 42.5 & 43.9 \\
\hline Giza83 & 82.0 & 76.2 & 64.3 & 30.8 & 33.9 & 35.1 & 24.3 & 22.0 & 20.0 & 42.2 & 43.3 & 44.0 \\
\hline Giza111 & 97.5 & 89.5 & 74.2 & 17.2 & 18.0 & 20.3 & 24.5 & 22.2 & 21.0 & 40.6 & 41.7 & 41.9 \\
\hline H30 & 97.2 & 88.5 & 74.3 & 18.0 & 19.0 & 21.0 & 23.2 & 21.0 & 18.0 & 37.0 & 37.9 & 38.2 \\
\hline H32 & 91.2 & 86.0 & 52.7 & 21.6 & 23.0 & 24.5 & 23.7 & 20.5 & 20.2 & 37.2 & 38.1 & 38.7 \\
\hline Toano & 83.8 & 71.8 & 63.5 & 32.1 & 34.8 & 36.7 & 25.3 & 21.5 & 19.3 & 36.6 & 37.6 & 38.2 \\
\hline DR101 & 90.6 & 74.2 & 66.7 & 20.9 & 21.1 & 24.7 & 24.3 & 23.8 & 18.8 & 33.6 & 34.5 & 35.5 \\
\hline H14L8 & 92.5 & 76.8 & 57.0 & 22.5 & 22.9 & 26.2 & 24.6 & 24.2 & 23.0 & 37.8 & 38.2 & 39.4 \\
\hline L162 & 84.8 & 76.2 & 61.7 & 27.8 & 32.7 & 34.3 & 24.9 & 22.6 & 20.3 & 37.1 & 37.9 & 38.8 \\
\hline Giza35 & 87.0 & 78.7 & 60.0 & 23.0 & 26.5 & 30.8 & 24.5 & 22.1 & 19.0 & 30.9 & 32.1 & 32.5 \\
\hline Holladay & 85.8 & 79.2 & 60.2 & 20.7 & 29.9 & 32.3 & 25.1 & 22.9 & 20.9 & 35.2 & 36.1 & 36.7 \\
\hline F-test & & $* *$ & & & ** & & & $* *$ & & & $* *$ & \\
\hline L.S.D 0.05 & & 2.17 & & & 0.37 & & & 0.27 & & & 0.23 & \\
\hline
\end{tabular}

Table 8. The correlation coefficient for the relationship between soybean genotypes and studied characters.

\begin{tabular}{|c|c|c|c|c|c|c|c|c|c|c|c|c|c|}
\hline & Character & $\mathbf{X} 2$ & X3 & $\mathrm{X} 4$ & X5 & X6 & $\mathbf{X} 7$ & $\mathrm{X8}$ & X9 & X10 & X11 & $\mathrm{X} 12$ & $\mathbf{X 1 3}$ \\
\hline $\mathrm{X} 1$ & Seed yield(t/fed) & $0.808 * *$ & $0.403 * *$ & $-0.176 \mathrm{~ns}$ & $0.432 * *$ & $0.355^{*}$ & $0.096 \mathrm{~ns}$ & $0.068 \mathrm{~ns}$ & $-0.186 n s$ & $-0.076 \mathrm{~ns}$ & $0.039 \mathrm{~ns}$ & $-0.150 \mathrm{~ns}$ & $-0.339 \mathrm{~ns}$ \\
\hline $\mathrm{X} 2$ & 100-seed weight (g) & & $0.346^{*}$ & $-0.117 \mathrm{~ns}$ & $0.292 \mathrm{~ns}$ & $0.011 \mathrm{~ns}$ & $0.049 \mathrm{~ns}$ & $-0.035 n s$ & $-0.159 \mathrm{~ns}$ & $0.009 \mathrm{~ns}$ & $-0.026 n s$ & $-0.123 n s$ & $-0.290 \mathrm{~ns}$ \\
\hline $\mathrm{X} 3$ & Germination \% & & & $0.544^{* *}$ & $0.598^{* *}$ & $-0.119 n s$ & $0.700^{* *}$ & $0.723 * *$ & $-0.606^{* *}$ & $0.735^{* *}$ & $0.600 * *$ & 0. & $-0.708 * *$ \\
\hline $\mathrm{X} 4$ & $\mathrm{EC}$ & & & & $0.268 \mathrm{~ns}$ & $0.024 \mathrm{~ns}$ & $-0.380 *$ & $-0.345^{*}$ & $0.203 \mathrm{~ns}$ & $-0.610 * *$ & $-0.689 * *$ & $-0.109 \mathrm{~ns}$ & $0.235 \mathrm{~ns}$ \\
\hline $\mathrm{X} 5$ & Oil\% & & & & & $-0.450 *$ & $0.684 * *$ & $0.607 * *$ & $-0.683^{* *}$ & $0.560^{* *}$ & $0.389 *$ & $0.187 \mathrm{~ns}$ & $-0.724 * *$ \\
\hline X6 & Protein \% & & & & & & $-0.367^{*}$ & $-0.333^{*}$ & $0.085 \mathrm{~ns}$ & $-0.360 \mathrm{~ns}$ & $-0.397 *$ & $-0.371^{*}$ & $0.028 \mathrm{~ns}$ \\
\hline $\mathrm{X} 7$ & Dry $m$ & & & & & & & $0.945 * *$ & $0.380 *$ & $0.856^{* *}$ & $0.621 * *$ & $0.481 * *$ & $-0.440^{*}$ \\
\hline X8 & Leaf area index & & & & & & & & $-0.319 n s$ & $0.853 * *$ & $0.612 * *$ & $0.554 * *$ & $-0.387 *$ \\
\hline X9 & RWC & & & & & & & & & $-0.331 \mathrm{~ns}$ & $-0.245 n s$ & $0.172 \mathrm{~ns}$ & 0.970 ** \\
\hline $\mathrm{X} 10$ & CGR & & & & & & & & & & $0.891 * *$ & $0.491 * *$ & $-0.372 *$ \\
\hline X11 & NAR & & & & & & & & & & & $0.362 *$ & $-0.261 \mathrm{~ns}$ \\
\hline $\mathrm{X} 12$ & Total chlorophyll & & & & & & & & & & & & $0.149 \mathrm{~ns}$ \\
\hline $\mathrm{X} 13$ & Proline & & & & & & & & & & & & 1.00 \\
\hline
\end{tabular}

$* *$ and NS indicated. to significant and not significant at $P<0.01$, respectively.

\section{REFERENCES}

A.O.A.C. (1990). Official Methods of Analysis of the Association of Official Analytical Chemists $15^{\text {th }}$ edition, published by Association of Official Analytical Chemists Arlington, Virginia, U.S.A.

Abass, S. M. and H. I. Mohamed (2011). Alleviation of adverse effects of drought stress on common bean (Phaseolus vulgaris L.) by exogenous application of hydrogen peroxide. Bangladesh J. Bot. 41: 75-83.

Abd El-Mohsen, A. A.; Gamalat O. Mahmoud and S.A. Safina(2013). Agronomical evaluation of six soybean cultivars using correlation and regression analysis under different irrigation regimes conditions. J. of Plant Breeding and Crop Sci. 5 (5):91-102.

Bates, L.S.; R.P. Waldern and I.D. Teave (1973). Rapid determination of free proline for water stress studies. Plant and Soil, 39: 205-207.

Burton, R.S. (1991). Regulation of proline synthesis during osmotic stress in the copepod Tigriopuscalifornicus. J. Exp. Zool., 259: 166-73.
Chung, J.; H.L. Babka; G.L.Graef; P.E. Staswick; D.J. Lee; P.B. Cregan;R.C. Shoemaker and J.E. Specht (2003). The seed protein, oil, and yield QTL on soybean linkage group I. Crop Sci.; 43(3): 1053-1067.

Desclaux, D.; T. T. Huynh and P. Roumet (2000). Identification of soybean plant characteristics that indicate the timing of drought stress. Crop Sci. 40:716-722.

Dornbos D.L. and R.E. Mullen (1992). Soybean seed protein and oil contents and fatty acid composition adjustments by drought and temperature. $\mathrm{J}$ of the American Oil Chem. Soc., 69(3): 228-231.

EL Sabagh, A; S. Sobhy, A. Omar, M. S. Islam; A. Ueda; H. Saneoka and C. Barutçular (2015) . Soybean (Glycine Max L.) growth enhancement under water stress conditions. Int. Conf. on Chem., Agric. and Bio. Sci. (CABS- 2015) Sept. 4-5, 2015 Istanbul (Turkey):144-148.

El-Borai, M. A.;M.M. Radi , M. B. Habeeb , F. H. Shalaby and Nadia A . El- Aidy (1993). Effect of some water stress regimes and plant population on yield and seed quality of soybean. J. Agric. Sci., Mansoura Univ. 18 (8): 2198-2205. 
El-Garhy, A.M.;M.Shaaban and A.A.El-Gammaal (2008).Effect of irrigation intervals on soybean yield and its components. J. Adv. Agric. Res .(Fac. Ag. SabaBasha ),13(3): 405-413.

Fougereux, J.A.;T. Dore; F. Ladonne and A. Fleury( 1997). Water stress during reproductive stages affects seed quality and yield of pea. Crop Sci., 37: 1247-1252.

Frederick, J.R; C.R. Camp, P.J. Bauer (2001). Drought stress effects on branches and main stem seed yield and yield components of determinate soybean. Crop Sci. 41:759-763.

Gardner F, Pearce R, Mitchell RL (1985). Physiology of Crop Plants.genetic variability and traits interrelationship among releasedgenetic variability, correlation and path analyses for yield and its genotypes under different plant density. Asian J. Crop Sci. ,4(4):1-9.

Gomez, K.A; and A.A. Gomez. (1984). Statistical procedures for agricultural research. John Wiley \&Sons, New York: Wiley- Interscience.

Henry J.L .and K.B .MacDonald (1978). The effects of soil and fertilizer nitroge and moisture stress on yield, oil and protein concentration of rape. Canada J. Soil Sci., 58: 303-310.

ISTA, (1999). International rules for seed testing, 1999. Supplement to Seed Sci. and Tech., 27: 27-32.

Latifi N (1989).Yield and morphological response of soybean to time of irrigation and sowing rate. Diss. Abstr. Int., 40: 5088-5098.

Moran, R. (1982). Formula determination of chlorophylls pigments extracted with N-N dimethyl- frmamid . Plant Physiol.,69: 1376-1381.

Morsy, A.R.; Rehab, A. Abdel-Rahman; W. M. Fares; A. A. A. El Hosary; M. A. Ibrahim; M. A. El-Noby and A. A. Abou-Zied (2017). Interpretation of genotype X environment interaction for soybean variety trials using different stability procedures. Egypt. J.Plant Breed., 21(5):536-553.

Omae, H.;A. Kumar; K. Kashiwaba and M. Shono( 2007). Assessing drought tolerance in snap bean (Phaseolus vulgaris) from genotypic differences in leaf water relations, shoot growth and photosynthetic parameters. Plant Prod. Sci., 10(1): 28-35.

Prisco, J.I.; C. R. Haddad and J.L P. Bastos (1992). Hydration- dehydration seed pre- treatment and its effects o seed germination under water stress conditions . Revista Brasileira Botanica,15:31-35

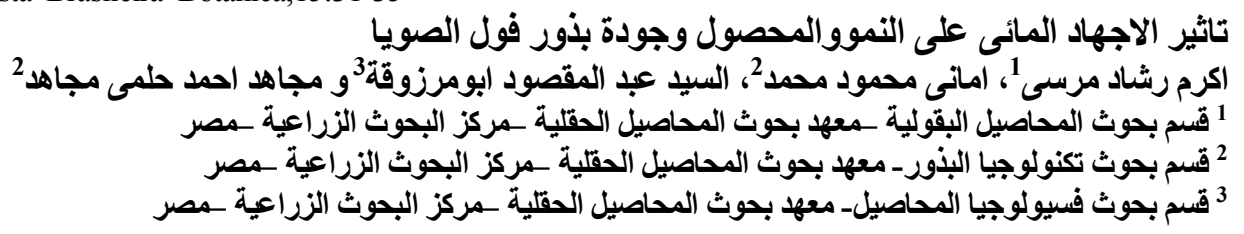

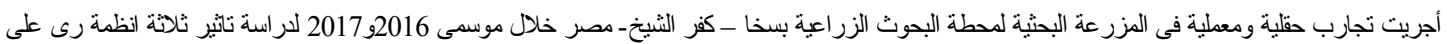

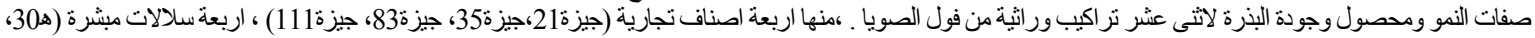

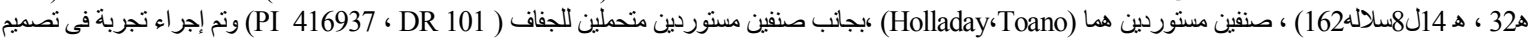

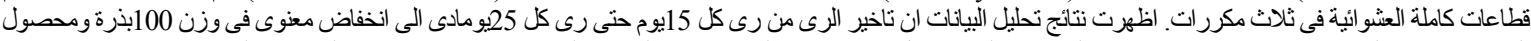

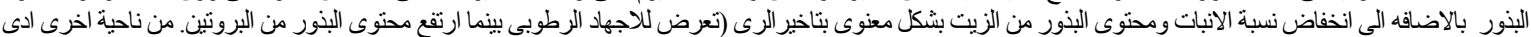

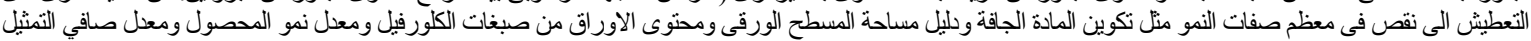

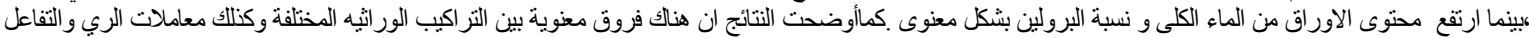

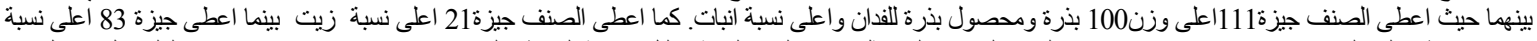

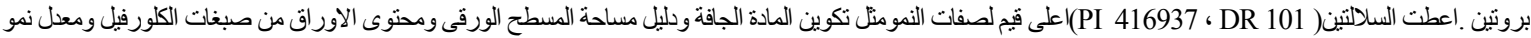

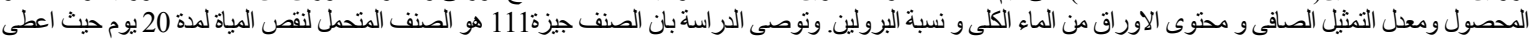

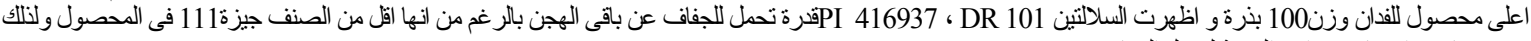
يوصى باستخدامهما فى برامج التربية لتحمل الجفاف. 